\title{
FAKTOR-FAKTOR YANG MEMPENGARUHI FINANCE BEHAVIOR ANGKATAN KERJA DI JAKARTA
}

\author{
Claudia Rara Anggitha \\ Program Studi Magister Manajemen Universitas Tarumanagara \\ claudiararaanggitha@gmail.com
}

Masuk : 05-06-2020, revisi : 26-06-2020 diterima untuk diterbitkan : 29-06-2020

\begin{abstract}
The purpose of this research is to analyze the influence of Level of Education, Financial Experience, Financial Attitude, Financial Knowledge and Locus of Control on Financial Behavior. The subjects of this research are work force in Jakarta. Sample was selected using convenience sampling method amounted to 100 respondents. Data processing techniques using structural equation modeling what helped by SmartPLS.3.0 program. The result of this study reveals that Level of Education, Financial Experience, Financial Attitude and Financial Knowledge do affect significantly on Financial Behavior, while Locus of Control does not affect significantly on Financial Behavior.
\end{abstract}

Abstrak: Tujuan dari penelitian ini adalah untuk menganalisis adanya pengaruh Tingkat Pendidikan, Pengalaman Keuangan, Sikap Keuangan, Pengetahuan Keuangan dan Lokus Kendali terhadap Perilaku Keuangan. Subjek penelitian ini adalah angkatan kerja di Jakarta. Sampel dipilih menggunakan metode convenience sampling berjumlah 100 responden. Teknik pengolahan data menggunakan pemodelan persamaan struktural yang dibantu oleh program SmartPLS.3.0. Hasil penelitian ini menunjukkan bahwa Tingkat Pendidikan, Pengalaman Keuangan, Sikap Keuangan, Pengetahuan Keuangan berpengaruh secara signifikan terhadap Perilaku Keuangan, sedangkan Lokus Kendali tidak berpengaruh signifikan terhadap Perilaku Keuangan.

Kata Kunci: Tingkat Pendidikan, Pengalaman Keuangan, Sikap Keuangan, Pengetahuan Keuangan, Lokus Kendali dan Perilaku Keuangan

\section{PENDAHULUAN}

Perilaku keuangan dapat dikaitkan sebagai suatu bentuk dari tanggung jawab seorang individu dalam mengelola keuangan individu tersebut agar kebutuhan jangka panjang dan jangka pendek dapat terpenuhi. Perilaku keuangan yang baik membantu masyarakat untuk terhindar dari masalah keuangan dan dapat mencapai kesejahteraan dalam hidup. Seperti saat ini ditengah wabah pandemi COVID-19, banyak timbulnya kasus-kasus kesulitan keuangan baik rumah tangga maupun perusahaan. Pada awalnya bermula dari self-carrantine yang memicu penurunannya konsumsi masyarakat terkecuali bahan pokok dan produk kesehatan sehingga hal ini mengakibatkan turunnya profit perusahaan dan berlanjut kepada keputusan perusahaan untuk melakukan Pemutusan Hubungan Kerja (PHK) bagi beberapa karyawannya.

Akibatnya sebagian dari masyarakat Indonesia mengalami kesulitan ekonomi, hal ini dibuktikan oleh survei nasional dari Saiful Mujani Research and Consulting (2020), yang dimana mengatakan bahwa Mayoritas rakyat Indonesia (77\%) menyatakan Covid 19 telah mengancam pemasukan atau penghasilan mereka. Lebih jauh lagi, sekitar $25 \%$ warga (atau 50 juta warga dewasa) menyatakan sudah tidak bisa lagi memenuhi kebutuhan pokok tanpa pinjaman; $15 \%$ warga menyatakan tabungan yang dimiliki hanya cukup untuk beberapa minggu; dan $15 \%$ warga menyatakan tabungan yang dimiliki hanya cukup untuk satu minggu. Berdasarkan hasil survei tersebut, dapat dipahami bahwa sebenarnya masyarakat Indonesia memang tidak memiliki persiapan seperti memiliki tabungan yang memadai untuk menghadapi situasi yang terjadi saat ini. 
Jika ditinjau dari beberapa survei sebelumnya, memang banyak dari masyarakat Indonesia yang masih memiliki perilaku keuangan yang buruk seperti membelanjakan kebutuhan jangka pendek tanpa mempertimbangkan kebutuhan jangka panjang. Seperti data dari Otoritas Jasa Keuangan (OJK) (Kompas, 2015) menyatakan bahwa di Indonesia Marginal Propensity to Save (MPS) mengalami penurunan dalam waktu 3 tahun terakhir, sebaliknya Marginal Propensity to Consume (MPC) mengalami kenaikan. Masyarakat Indonesia memiliki kecenderungan konsumtif yang sangat tinggi sehingga dapat disimpulkan bahwa masyarakat Indonesia kurang bijak dalam mengalokasikan pendapatan mereka. Hal ini dapat ditunjukkan melalui kurangnya kegiatan menabung, investasi, pengaturan untuk dana darurat, dan perencanaan dana untuk masa depan. Berdasarkan dari perumusan masalah diatas, maka tujuan dari penelitian ini untuk mengetahui pengaruh Tingkat Pendidikan, Pengalaman Keuangan, Sikap Keuangan, Pengetahuan Keuangan dan Lokus Kendali terhadap Perilaku Keuangan (Perilaku Keuangan) kelompok angkatan kerja di Jakarta.

\section{TINJAUAN PUSTAKA}

\section{Theory of Reasoned Action}

Menurut Ajzen dan Fishbein (1980) dalam Arifin (2017) bahwa teori ini mengatakan bahwa adanya niat dipengaruhi oleh dua penentu dasar yaitu sikap (attitude) dan juga norma subjektif (subjective norm). Oleh karena itu, ada atau tidaknya suatu niat (intention) seseorang individu untuk menentukkan dilakukan atau tidaknya suatu perilaku (behavior).

\section{Theory of Planned Behavior}

Teori Perilaku Terencana merupakan pengembagan dari Teori Perilaku Beralasan, dimana terdapat satu tambahan penentu dasar yaitu kontrol perilaku yang dipersepsikan (Perceived Behavioral Control) Menurut Ajzen (1991:206), Teori perilaku beralasan mengungkapkan bahwa Sikap terhadap perilaku (Attitude Towards Behavior), norma subyektif (Subjective Norm) sehubungan dengan perilaku, dan kontrol yang dirasakan (Perceived Behavioral Control) atas perilaku biasanya ditemukan untuk memprediksi niat perilaku (Intention) dengan tingkat akurasi yang tinggi.

\section{Tingkat Pendidikan}

Survei yang dilakukan oleh Otoritas Jasa Keuangan (2017) menemukan bahwa individu yang memiliki tingkat pendidikan yang lebih tinggi cenderung memiliki preferensi terhadap produk dan layanan jasa keuangan yang lebih beragam, sehingga Individu tidak hanya memiliki pengertian tentang produk dan layanan jasa keuangan pada perbankan hanya sebatas dari tabungan saja, melainkan terdapat deposit, kredit, mata uang asing, dan masih banyak lagi. Selain perbankan, individu akan mengerti mengenai produk dan layanan jasa keuangan lain seperti hal nya asuransi, pensiun, pengadaian, saham, obligasi dan lain-lain. Hal ini menyebabkan pilihan yang beragam membantu meningkatkan penghasilan mereka yang hanya sekedar penghasilan utama, fungsi lainnya lagi adalah sebagai bentuk spekulasi dan berjagajaga di masa depan sehingga perpaduan ini menghasilkan Perilaku Keuangan yang baik.

\section{Pengalaman Keuangan}

Pengalaman Keuangan adalah suatu kejadian tentang hal yang berhubungan dengan keuangan yang pernah dialami (dijalani, dirasakan, ditanggung dan sebagainya) baik yang sudah lama atau baru saja terjadi oleh seseorang individu dan dijadikan suatu pembelajaran agar individu tersebut dapat mengelola keuangannya lebih baik lagi serta menghindari kegagalan yang pernah terjadi sebelumnya. Pengalaman Keuangan (Pengalaman Keuangan) ini juga dapat dipelajari dari pengalaman pribadi, keluarga, teman-teman atau orang lain yang lebih berpengalaman, hal ini membantu individu tersebut dalam merencanakan, mengelola, dan mengambil keputusan keuangan, sehingga hal-hal ini mampu menjadikan Pengalaman Keuangan seseorang menjadi baik. 


\section{Sikap Keuangan}

Sikap Keuangan merupakan keadaan pikiran, pendapat, serta penilaian yang dilakukan oleh individu tentang keuangannya serta sikap yang dimiliki seseorang terhadap uangannya dalam mengambil keputusan keuangan, keputusan ini yang akan menentukan baik atau buruknya Perilaku Keuangan individu.

\section{Pengetahuan Keuangan}

Seseorang dapat memiliki pengetahuan keuangan dengan cara meningkatkan keterampilan keuangan (financial skill) dan belajar mengenai penggunaan peralatan keuangan (financial tools) (Ida dan Dwinta, 2010), semakin seseorang meningkatkan keterampilan keuangannya maka seseorang akan memiliki pilihan yang beragam untuk keputusan keuangan yang mampu membuat perilaku keuangan individu semakin baik. Berdasarkan uraian di atas, maka dapat disimpulkan bahwa pengetahuan keuangan adalah suatu pemahaman yang diperoleh individu mengenai konsep-konsep dan pengetahuan individu mengenai keuangan pribadi yang dibutuhkan untuk mengelola serta mengambil keputusan berkaitan dengan keuangan. Pentingnya pengetahuan keuangan juga membantu kita untuk terhindar dari berbagai macam kejahatan dan penipuan yang mengatasnamakan instrumen, produk dan jasa layanan keuangan dan perbankan.

\section{Lokus Kendali}

Lokus kendali mampu menggambarkan seberapa jauh pengaruh dari perbuatan yang dilakukan oleh individu terhadap akibat/hasil yang akan diterimanya. Lokus kendali dibagi menjadi dua yaitu lokus kendali internal dan eksternal. Hal ini dikarenakan individu dengan lokus kendali internal akan percaya dengan mampu mengendalikan dirinya pada saat ini (seperti mengelola keuangan, melakukan kegiatan menabung, investasi, perencanaan hari tua, dll) dapat menghindari masalah finansial di masa depan. Di sisi lain, individu dengan lokus kendali eksternal akan kurang bertanggung jawab atas perilaku keuangannya. Individu dengan lokus kendali eksternal dalam hidupnya cenderung menganggap hidup mereka ditentukan oleh kekuatan dari luar diri mereka seperti nasib, keberuntungan, atau orang lain. Individu tersebut akan kurang berusaha atas apa yang akan terjadi pada hidupnya karena individu cenderung berpikir jangka pendek dan bergantung pada faktor eksternal untuk jangka panjangnya.

\section{Perilaku Keuangan}

Perilaku Keuangan berkaitan cara mengelola dana yang ada secara bertanggung jawab atas proses pengelolaan uang dan aset lainnya dengan baik dan bertanggung jawab. Cara bertanggung jawab keuangan adalah proses proses menguasai asset keuangannya dan penggunaan dana atau keuangan serta aset yang lain dengan produktif, baik dan bijak (Ida \& Dwinta, 2010:132). Perilaku Keuangan adalah serangkaian gabungan dari beberapa sumber aspek yang menjadi dasar dalam pengambilan keputusan individu dalam melakukan perencanaan, pengelolaan, menabung, berinvestasi dan lain-lain.

Berdasarkan dari penjelasan setiap variabel, Tingkat Pendidikan, Pengalaman Keuangan, Sikap Keuangan, Pengetahuan Keuangan dan Lokus Kendali terhadap perilaku keuangan berikut hipotesis yang diperoleh:

H1 : Level of Education (Tingkat Pendidikan) memiliki pengaruh yang signifikan terhadap Financial Behavior (Perilaku Keuangan) kelompok angkatan kerja di Jakarta

$\mathrm{H} 2$ : Financial Experience (Pengalaman Keuangan) memiliki pengaruh yang signifikan terhadap Financial Behavior (Perilaku Keuangan) kelompok angkatan kerja di Jakarta

H3 : Financial Attitude (Sikap Keuangan) memiliki pengaruh yang signifikan terhadap Financial Behavior (Perilaku Keuangan) kelompok angkatan kerja di Jakarta

H4 : Financial Knowledge (Pengetahuan Keuangan) memiliki pengaruh yang signifikan terhadap Financial Behavior (Perilaku Keuangan) kelompok angkatan kerja di Jakarta

H5 : Locus of Control (Lokus Kendali) memiliki pengaruh yang signifikan terhadap Financial Behavior (Perilaku Keuangan) kelompok angkatan kerja di Jakarta 


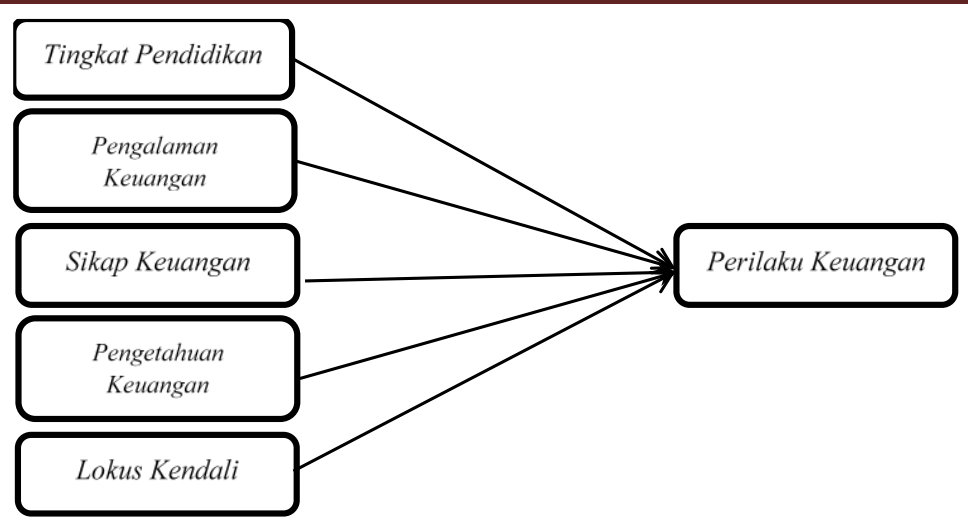

\section{Gambar 1 \\ Kerangka Pemikiran}

\section{METODOLOGI PENELITIAN}

Penelitian ini menggunakan kuesioner yang disebar menggunakan google form kepada para responden, yang tidak lain adalah angkatan kerja di Jakarta. Jumlah sampel yang digunakan dalam penelitian ini adalah sejumlah 100 responden. Pemilihan sampel dilakukan dengan menggunakan convinience sampling, karena memudahkan pengumpulan sampel berdasarkan populasi yang mudah dijangkau oleh peneliti yaitu angkatan kerja di Jakarta. Variabel operasional dalam penelitian ini terdiri dari Tingkat Pendidikan, Pengalaman Keuangan, Sikap Keuangan, Pengetahuan Keuangan dan Lokus Kendali sebagai variabel independen dan perilaku keuangan sebagai variabel dependen. Dalam penelitian ini menggunakan uji outer model, inner model, dan pengujian hipotesis.

\section{Tabel 1}

Hasil Bootsrapping

\begin{tabular}{|l|l|l|l|}
\hline Variabel & Path Coefficients & T Statistics & P Value \\
\hline Tingkat Pendidikan $\rightarrow$ Perilaku Keuangan & 0,183 & 2,788 & 0,006 \\
\hline Pengalaman Keuangan $\rightarrow$ Perilaku Keuangan & 0,219 & 2,518 & 0,012 \\
\hline Sikap Keuangan $\rightarrow$ Perilaku Keuangan & 0,410 & 4,456 & 0,000 \\
\hline Pengetahuan Keuangan $\rightarrow$ Perilaku Keuangan & 0,140 & 2,110 & 0,035 \\
\hline Lokus Kendali $\rightarrow$ Perilaku Keuangan & 0,167 & 1,837 & 0,067 \\
\hline
\end{tabular}

Berdasarkan hasil dari pengujian outer model, dapat disimpulkan bahwa seluruh variabel dalam penelitian ini sudah valid dan reliabel. Selain itu, dapat dilihat dari hasil pengujian inner model yang terdiri dari koefisien determinasi $\left(\mathrm{R}^{2}\right)$ dengan hasil dalam penelitian ini $73,6 \%$ dari variabel dependen yaitu Perilaku Keuangan dapat dijelaskan oleh variabel-variabel yang terdapat dalam penelitian ini, predictive relevance $\left(\mathrm{Q}^{2}\right)$ dengan hasil $37,7 \%$, hal ini membuktikan seluruh variabel dapat memprediksi model dengan baik, path coeffiecients, effent size $\left(\mathrm{f}^{2}\right)$, dan pengujian kolineritas. Hasil pengujian effect size $\left(\mathrm{f}^{2}\right)$ menyatakan bahwa variabel Tingkat Pendidikan memiliki efek perubahan yang lemah terhadap Perilaku Keuangan yaitu sebesar 0,088. Variabel Pengalaman Keuangan memiliki efek perubahan yang lemah terhadap Perilaku Keuangan yaitu sebesar 0,073. Variabel Sikap Keuangan memiliki efek perubahan yang besar atau kuat terhadap Perilaku Keuangan yaitu sebesar 0,400. Variabel Pengetahuan Keuangan memiliki efek perubahan yang lemah terhadap Perilaku Keuangan yaitu sebesar 0,037. Variabel Lokus Kendali memiliki efek perubahan yang lemah terhadap Perilaku Keuangan yaitu sebesar 0,055. Hasil pengujian path coefficients dapat disimpulkan bahwa nilai prediksi dari Tingkat Pendidikan terhadap Perilaku Keuangan memiliki arah positif yaitu sebesar 0,183; nilai prediksi dari Pengalaman Keuangan terhadap Perilaku Keuangan memiliki arah positif yaitu sebesar 0,219; nilai prediksi dari Sikap Keuangan terhadap Perilaku Keuangan memiliki arah positif yaitu sebesar 0,410; nilai prediksi dari Pengetahuan Keuangan terhadap Perilaku Keuangan memiliki arah positif yaitu sebesar 0,140; nilai prediksi dari Lokus Kendali terhadap Perilaku Keuangan memiliki arah positif yaitu sebesar 0,167. 


\section{HASIL \& KESIMPULAN}

Hasil pengujian bootsrapping menunjukkan bahwa variabel Tingkat Pendidikan, Pengalaman Keuangan, Sikap Keuangan dan Pengetahuan Keuangan berpengaruh signifikan terhadap Perilaku Keuangan dan variabel Lokus Kendali tidak berpengaruh signifikan terhadap Perilaku Keuangan. Tingkat Pendidikan memiliki pengaruh yang signifikan dan positif diasumsikan karena mayoritas responden dari penelitian ini memiliki tingkat pendidikan S1, responden memiliki lebih banyak preferensi penggunaan produk dan jasa keuangan lainnya. Manfaat-manfaat dari penggunaan produk dan jasa keuangan ini yang mampu mendorong individu untuk memiliki Perilaku Keuangan yang lebih baik.

Hasil dari penelitian ini menunjukkan bahwa Pengalaman Keuangan memiliki pengaruh dan positif terhadap Perilaku Keuangan, diartikan bahwa semakin baik Pengalaman Keuangan seseorang maka semakin baik pula Perilaku Keuangan. Indikator yang paling berpengaruh dalam kesuksesan Pengalaman Keuangan merupakan Pentingnya memiliki tabungan jangka panjang, sehingga menjelaskan bahwa seseorang yang menginginkan Pengalaman Keuangan yang baik maka individu tersebut harus menganggap kebutuhan jangka panjang sebagai sesuatu yang penting dan harus dilakukan perencanaan dan pelaksanaan mulai dari dini sehingga kebutuhan yang dibutuhkan di masa depan tersebut dapat terpenuhi pada waktunya.

Hasil dari penelitian ini menunjukkan bahwa Sikap Keuangan memiliki pengaruh dan positif terhadap Perilaku Keuangan, yang dimana berarti Sikap Keuangan seseorang berarti semakin baik juga Perilaku Keuangan yang dimiliki individu tersebut. Dapat dilihat dari indikator Sikap Keuangan bahwa indikator yang paling berpengaruh terhadap Perilaku Keuangan adalah menentukan prioritas pengeluaran, yang dimana individu sadar pentingnya pengelolaan pengeluaran agar tidak terjebak dalam Sikap Keuangan yang buruk. Hal ini akan membantu seseorang untuk memperoleh pola sikap yang baik dimana agar individu tersebut dapat mengelola keuangan yang lebih baik, seperti mengutamakan kewajiban-kewajibannya sebagai prioritas pengeluaran, bukan mengutamakan segala keinginannya terlebih dahulu baru menjalankan kewajiban.

Hasil dari penelitian ini menunjukkan bahwa Pengetahuan Keuangan memiliki pengaruh dan positif terhadap Perilaku Keuangan, sehingga dapat disimpulkan bahwa semakin baik Pengetahuan Keuangan seseorang maka semakin baik pula Perilaku Keuangan. Dapat dilihat dari indikator pengetahuan keuangan bahwa indikator yang paling berpengaruh terhadap perilaku keuangan adalah individu mengetahui istilah credit rating dan credit files. Jadi untuk mempunyai perilaku keuangan yang baik dan bertanggung jawab individu terlebih dahulu harus mengetahui istilah credit rating dan credit files agar dapat mengelola keuangan kredit mereka dengan baik.

Hasil dari penelitian ini menunjukkan bahwa Lokus Kendali tidak memiliki pengaruh dan positif terhadap Perilaku Keuangan. Hal ini dapat disimpulkan bahwa tinggi rendahnya Lokus Kendali tidak dapat mempengaruhi baik atau buruknya Perilaku Keuangan, dikarenakan individu dengan lokus kendali eksternal cenderung memiliki perilaku keuangan yang buruk, penyebabnya adalah karena kurangnya rasa bertanggung jawab dalam berperilaku keuangan. Apabila dikaitkan dengan subjek penelitian yang dimana mayoritas jenis kelamin ialah perempuan dan mayoritas umur pada 15-24 tahun, dimana disimpulkan kebanyakan responden masih tinggal bersama orang tua sehingga mereka masih bergantung dengan orang tua atau orang-orang di sekitar mereka untuk bertahan hidup.

\section{DAFTAR PUSTAKA}

Ajzen, I. (1991). The Theory of planned behavior. Organizational Behavior and Human Decision Processes, 50, 179-211. ISSN: 0749-5978

Arifin, A. Z. (2017). The Influence of financial knowledge, control and income on individual financial behavior. European Research Studies Journal, 20(3A), 635-648. ISSN: 21486018 
Ida, \& Dwinta, C. Y. (2010). Pengaruh locus of control, financial knowledge, income terhadap financial management behavior. Jurnal Bisnis dan Akuntansi, 12(3), 131-144. ISSN: $1410-8975$

Kompas. (2015, Agustus 08). OJK: Orang Indonesia Makin Konsumtif. Retrieved Oktober 10, 2018 , from https://ekonomi.kompas.com/read/2015/08/08/110746226/OJK.Orang.Indonesia.Makin .Konsumtif

Mujani, S. (2020, April 7). Mayoritas Warga Anggap COVID-19 Ancam Penghasilan. https://saifulmujani.com/mayoritas-warga-anggap-covid-19-ancam-penghasilan/

Otoritas Jasa Keuangan. (2017). Strategi Nasional Literasi Keuangan Indonesia. 